\title{
Tree ring-based reconstruction of October to November runoffs in the Jiaolai River since 1826
}

L. $\mathrm{Ma}^{1}$, T. X. Liu ${ }^{1}$, Q. $\mathrm{Wu}^{2}$, L. H. $\mathrm{Ji}^{1}$, and R. Z. Gao ${ }^{1}$

${ }^{1}$ Water Conservancy and Civil Engineering College of Inner Mongolia Agricultural University, Hohhot, Inner Mongolia, 010018, China

${ }^{2}$ Land Surveying and Planning Institute of Inner Mongolia, Hohhot, Inner Mongolia, 010010, China

Received: 9 December 2011 - Accepted: 13 December 2011 - Published: 3 January 2012 Correspondence to: L. Ma (malong4444333@163.com)

Published by Copernicus Publications on behalf of the European Geosciences Union.

Tree ring-based reconstruction in the Jiaolai River since 1826

L. Ma et al.

Title Page

Abstract

Conclusions

Tables

References

Figures

14

4

Back

Full Screen / Esc

Printer-friendly Version

Interactive Discussion 


\section{Abstract}

The Horqin Sandy Land is a typical desertification region in China hounded by ecological and environmental problems, which continue to affect economic and social development.Hence,hydrological climate changes in this region need to be investigated.

5 The current study reconstructed the runoff sequences in the southwest edge of the LiaoHe River into the XiaWa station of the JiaoLai River during the months of October to November from 1826 to 2005. A comprehensive timeline for the regional tree wheel width of the Horqin Sandy Land was employed. The timeline has been in use for $183 \mathrm{yr}$. For the past $180 \mathrm{yr}$, the runoff has experienced six and four consecutive Feng and dry 10 sections, respectively. From 1982 to 2005, the runoff reached the longest section of a continuous low-flow runoff, with the mean average runoff amounting to only $63.58 \%$ of the entire period. Runoff has 3-, 11-, 15-, 24-, and 30-yr quasi-periodic variations, consistent with changes in similar areas worldwide. The period of 1826 to 1917 presents a more gentle change. In 1956, the runoff increased, and then significantly decreased for 15 nearly $50 \mathrm{yr}$. The drop rate is 1.7766 million $\mathrm{m}^{3} / 10 \mathrm{yr}$, which shows a consistent downward trend with the precipitation $(14.74 \mathrm{~mm} / 10 \mathrm{yr})$. The overall reduction in precipitation accounts for $29.86 \%$ of the initial value, which is far less than $75.58 \%$ of the runoff. If the runoff and precipitation drop continue, more extensive and longer ecological and environmental problems are foreseen to occur.

\section{Introduction}

China is one of several countries experiencing severe desertification. The rapid progression of dry land degradation has become an important ecological and socioeconomic problem (Wang et al., 2002; Wang and Zhu, 2001). The Horqin Sandy Land is located between east longitude $117^{\circ} 45^{\prime}$ to $124^{\circ} 06^{\prime}$ and north latitude $42^{\circ} 36^{\prime}$ to $45^{\circ} 20^{\prime}$

25 (Fig. 1). It belongs to the alluvial plain of the Liaohe River. In ancient times, the Horqin Sandy Land was a prairieland with lush vegetation and beautiful sceneries. Now, it
HESSD

$9,65-91,2012$
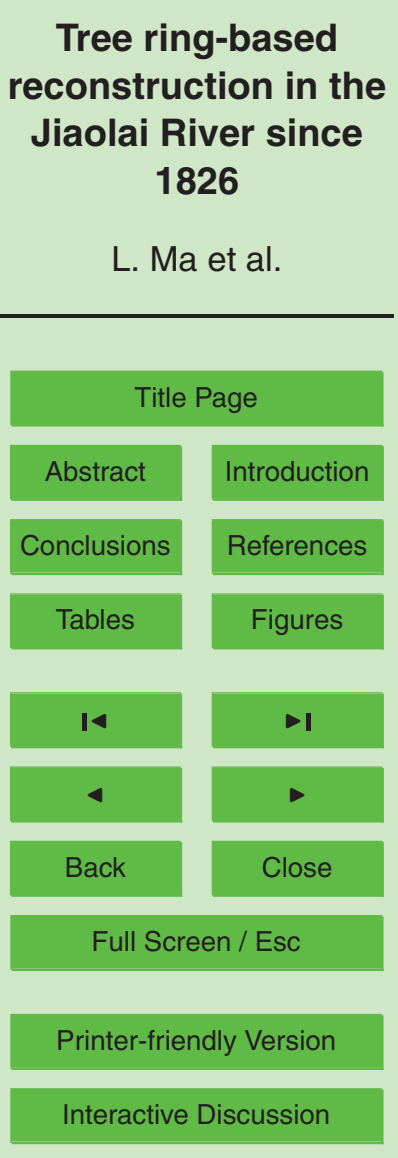

Interactive Discussion 
has become a typical Chinese desertification area, one of China's four sandy lands. Related research on the environmental changes in this area has begun in the 1950s, producing some substantive results (Wang and Zhu, 2001; Dong et al., 1998; Wang et al., 2004a, 2006; Li et al., 2007; Zhao et al., 2008) on the desertification process, evo5 lution, structure, and drive mechanism. The results suggest that climate fluctuations could directly affect to some extent the process of desertification via through the different periods of precipitation and temperature combinations (Wang et al., 2004b; Zhao et al., 2008). The desertification is mainly subjected to millennial- and centennial-scale climate fluctuations (Dong et al., 1998). Hence, a long-time-scale research on hydro10 logical climate changes is particularly important.

Runoff and precipitation are closely related. The amount of runoff not only directly affects river ecology, but also has a profound impact on changes in river environments. Consequently, future trends in the ecological environment and past runoff variations need to be explored.

15 A number of studies have been conducted on runoffs in the Liaohe River. This river is located in the Horqin Sandy Land (Zhang et al., 2007; Hao et al., 2008; Yang et al., 2009; Fang et al., 2009; Jiang et al., 2009; Wang et al., 2011; Zhang and He, 2011; Gu et al., 2011), and the study period covers the years 1950s to 2008. The research involved the Liaohe River, the Liaohe tributaries, and other tributaries of the Laoha River. Zhang et al. (2007) have shown that the measured runoff in the Liaohe Laoha River has significantly decreased since 1950. Fang et al. (2009) have revealed that from the 1960 s to the early 21 st century, the variations in annual runoff and the annual runoff coefficient of the Laoha River were more-less-less-more-less. The decadal variation is much greater than the annual rainfall, and Wang et al. (2011) have pointed out that mid-1960s.

However, these studies are mainly based on observational data from hydrological observation stations, and the data life is generally $50 \mathrm{yr}$. These data are clearly insufficient for studying longer-time-scale changes in runoff. The hydro-climatic information
HESSD

9, 65-91, 2012

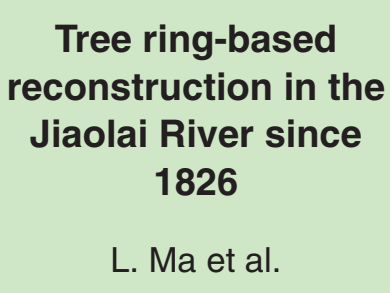

Title Page

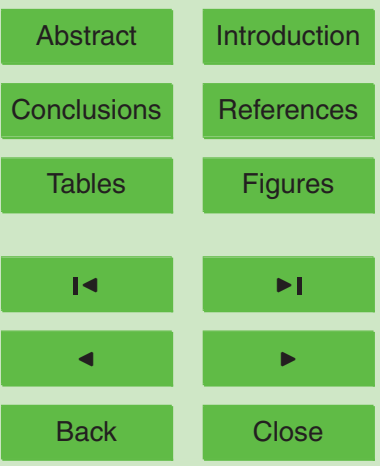

Full Screen / Esc

Printer-friendly Version

Interactive Discussion 
revealed by tree-ring records is an effective means to address this limitation. Tree ringbased reconstructions present information that feature accurate positioning, good continuity, high resolution, and precise correlation with hydrological climate change (Fritts, 1976; Shao, 1997a; Nicoletta, 2004). Such reconstructions are applied in research 5 on hydro-climatic events abroad, such as runoff, drought, flood, rainfall, temperature, glaciation, and volcanic activity (Stockton and Meko, 1975; Hughes et al., 1978; Cook and Jacoby, 1983; Briffa et al., 1995; Van et al., 1998; Clevel, 2000; Magda et al., 2001; Meko et al., 2001; Woodhouse, 2001; Esper et al., 2003; Law et al., 2006; Michael et al., 2006; Joseph et al., 2006; Sophie et al., 2007; Giovanna et al., 2010; Samuli et al., 10 2010).

In China, to study the chronology established, the tree ring and hydrological climate relationship, as well as the reconstruction, the study objects of Sabina, spruce, pine, white stick, larch, and elm in cold and dry regions were selected. Such regions included the Qinghai-Tibet Plateau, Qaidam Basin, Xinjiang, Qilian Mountain, Changbai 15 Mountain, Qinling, and Inner Mongolia. The research has made great progress (Wu et al., 1989; Shao et al., 1997b, c; Gou et al., 2006; Ma and Liu, 2007; Zhu et al., 2008; Eryuan et al., 2008; Liu et al., 2004, 2009a, 2010; Li et al., 2010; Ma et al., 2011). Part of the runoff is reconstructed in the Urumqi mountain basin, Black River, Tongtianhe, Huangshui, and Yellow River (Li et al., 1997; Kang et al., 2002, 2008; Qin et al., 2004; Wang et al., 2004; Liu et al., 1997b, 2007; Sun et al., 2011). The long sequence of changes in runoff characteristics are analyzed.

Regardless of short time changes in runoff characteristics and the reconstruction of a long sequence, studies on the JiaoLai River are relatively limited. In the current paper, the 183-yr Horqin sandy area elm tree ring width chronologies established by Ma et al. (2011) in a station in the JiaoLai River tributary during the months of October to November from 1826 to 2005 was used to study the runoff characteristics. The results provide some basic information on long-term changes in the Liaohe source runoff, ecological and environmental protection, as well as catchment economy progress.
HESSD

9, 65-91, 2012

\section{Tree ring-based reconstruction in the Jiaolai River since 1826 \\ L. Ma et al.}

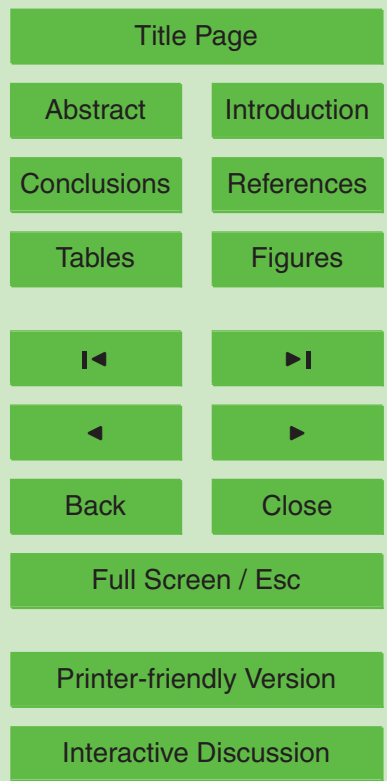




\section{Data used}

HESSD

\subsection{Chronological data}

The ring width chronology and reconstruction of elm in the Sandy Land were used (Ma and Liu, 2011). The ring width chronology for 1826 to 2008 (183 yr) is shown in Fig. 2 5 (Ma and Liu, 2011).

\subsection{Hydrological and meteorological data}

The precipitation data selected were in accordance with the chronology of the establishment of meteorological stations. The 1951 to 2010 monthly (year) precipitation data were obtained from the eight meteorological stations closest to the sites. These stations were the Horqin Left Back Banner, TongLiao, Kailu, Horqin Left Middle Banner, Jarud Qi, Horqin Right Middle Banner, and Horqin Left Right Banner. Data from meteorological administration-integrated materials were also obtained. The uniformity of every meteorological element indicated that precipitation data from the sites did not exhibit significant deviations as well as random changes, and that data changes were relatively homogenous and consistent. Hence, the data were considered as reliable representations of the climate conditions in the region. Data from adjacent sites were used to interpolate measurements because some of the stations had incomplete information. The average data of the eight stations were used for area face value.

According to the same basin and proximity principle, the monthly (yearly) runoff data from 1957 to 2010 of the Xiawa station in the JiaoLai River were collected. This station is located at the edge of the Horqin Sandy Land and the import point to the sand of the JiaoLai River. There is less human activity upstream, so the measured runoff data was closer to the natural values.

The ground precipitation in the Horqin Sandy Land is basically the same with the precipitation in the upstream watershed area. By combining all factors, the selected precipitation sites and hydrological stations were used in the present study.
9, 65-91, 2012

Tree ring-based reconstruction in the Jiaolai River since 1826

L. Ma et al.

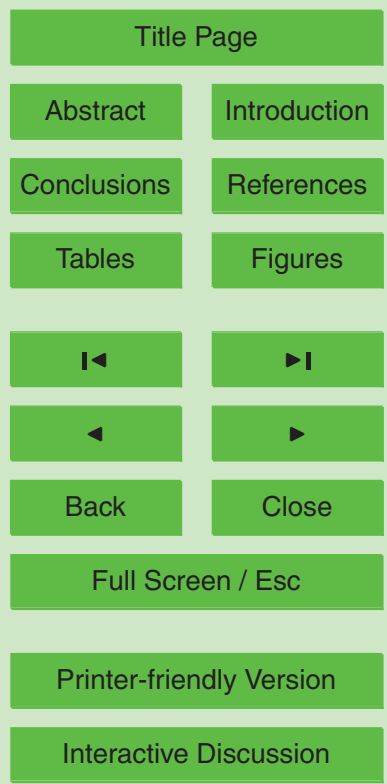

Interactive Discussion 


\section{Related analysis and explanation}

\subsection{Correlation of chronology and runoff}

Tree ring climatology considers that rings formed in the year $t$ are influenced not only by the climate at that time, but also by the climate of the previous 1 to $2 \mathrm{yr}$ (Fritts,

5 1976). Therefore, the standard chronological sequence and standard chronological $t+1, t+2$, and $t+3$ sequences in relation to the runoff in low-lying stations, as well as the correlation coefficients are shown in Table 1. The standard chronology had a significant relationship with the runoff in March, April, August, September, October, and November, as well as the annual runoff. The correlation in October and November was 10 the highest.

The results of the correlation analysis between the annual and monthly runoffs show that the runoff in July accounted for $30.19 \%$ of the annual runoff, and had the maximum correlation coefficient of 0.814 . Although the runoff in October and November were responsible for only $4.82 \%$ and $3.63 \%$ of the annual runoff, the annual runoff coefficient ranked only second to July; the coefficients were 0.755 and 0.699 , respectively, ranking second and third. Based on the contrast curve among the annual runoff, runoff in October, runoff in November, and runoff in October to November (Fig. 3), the four curves were concluded to have basically the same trend. Therefore, using a rebuilding chronology for the October-November runoff to analyze wet and dry season changes, cycle changes, which can represent the changes in annual runoff to some degree, were constructed. The reconstruction can also be carried out in August, considering the better correlation coefficients in October-November, which has a more significant meaning in reconstruction.

HESSD

9, 65-91, 2012
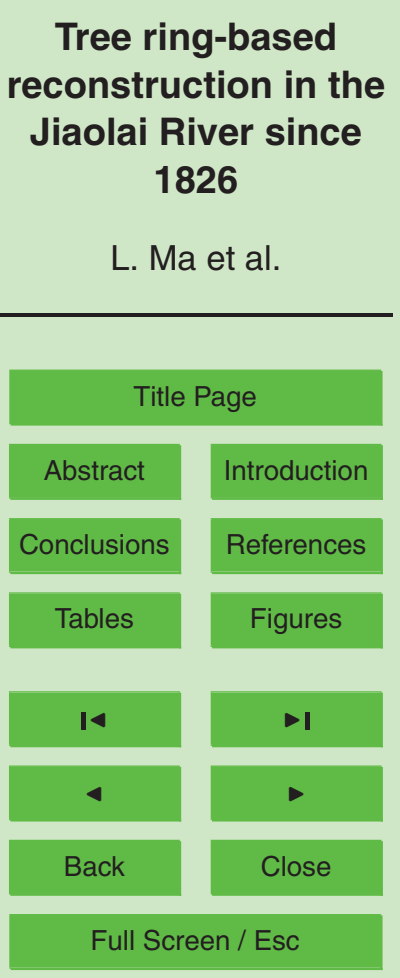

Printer-friendly Version

Interactive Discussion 


\subsection{Physiological mechanism explanation on the relationship between trees and runoff}

The main supply source of runoff formation is precipitation. In different seasons and at different times, the groundwater comes from direct precipitation or snowmelt, and 5 then supplies the runoff. According to the correlation between the precipitation sequence in the Horqin Sand Land and the runoff series in the XiaWa station (Table 2), the precipitation in July, August, and September, as well as the annual precipitation significantly correlated with the March to April, July to November, and annual runoffs. Among them, the precipitation in July had a significant correlation with the March to

10 April, July to November, and annual runoffs, respectively. The runoff in July accounted for $30.19 \%$ of the annual runoff, whereas precipitation in July was $32.18 \%$ of the total annual precipitation, which was the largest contribution to the runoff. Rainfall in August was significantly related to the August to October runoff, and the August runoff accounted for $24 \%$ of the annual runoff. On the other hand, the precipitation in August accounted for $21.46 \%$ of the annual precipitation, and ranks second in terms of runoff contribution. The precipitation in September had a significant correlation with the September to November runoff, and the runoff in September was $7.51 \%$ of the annual runoff. In contrast, precipitation in September accounted for $8.84 \%$ in the total annual precipitation. Annual precipitation was significantly related to the March to April, July to November, and annual runoffs. When precipitation transforms, some of it directly forms surface runoff, and some permeates the ground to supply surface runoff in the underground runoff form. Based on a combination of the above relationship, the formation of precipitation runoff can be concluded to have some lag. Therefore, the precipitation in July, August, as well as September, was greater, and accounted for a significant 25 proportion in the annual precipitation. The precipitation not only plays an important role in the formation of monthly surface runoff, but also affects the runoff information in October to November to some degree.

\section{HESSD}

9, 65-91, 2012

\section{Tree ring-based reconstruction in the Jiaolai River since 1826 \\ L. Ma et al.}

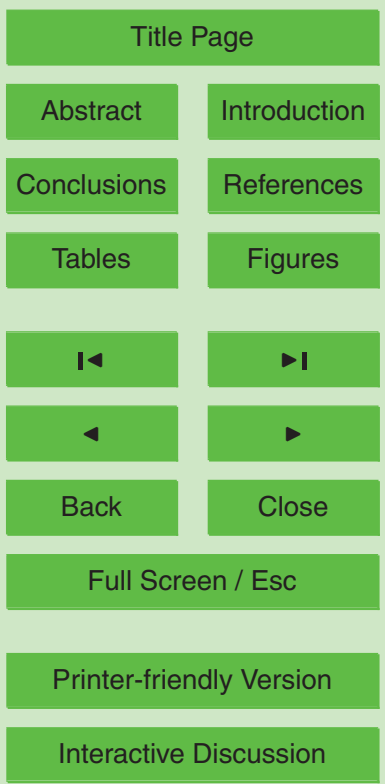


Precipitation also plays an important role in the growth of trees, especially the precipitation in July, August, and Sep, which were significantly correlated with the chronology (Ma et al., 2011). Summer was the peak of elm growth. At that time, elm growth depended most on water. Good water conditions during this period effectively and rapidly 5 promoted elm growth. This phenomenon was the same in September

Considering the comprehensive situations in Tables 1 and 2, Fig. 4 shows that precipitation played a major role in runoff formation and tree growth. In July, August, and September, the precipitation not only played an important role on tree growth, but also on runoff formation. Changes in the runoff also represented changes in precipitation. 10 Considering the lag effect, the precipitation in July, August, and September had a significant impact on the runoff in October to November This phenomenon explained the good relationship between the chronology and the August to November runoff. The good relationship among the chronology sequences in years $t+1, t+2$, and $t+3$ with the runoff also fully illustrated the delayed runoff response.

\section{Reconstruction runoff}

From the above response relationship, the standard sequence and standard chronology in years $t+1, t+2$, and $t+3$ were used to reconstruct runoff in the XiaWa station of the JiaoLai River from October to November since 1826 to 2005. The following equation was adopted:

$$
\begin{aligned}
& R_{t}=-800.79+438.43 \times I_{t}+98.01 \times I_{t+1}+231.54 \times I_{t+2}+818.15 \times I_{t+3} \\
& \left(N=49, r=0.74, R^{2}=0.54, R_{\mathrm{adj}}^{2}=0.51, F(4,44)=13.05, P<0.001\right)
\end{aligned}
$$

where $R_{t}$ is the runoff from October to November in year $t, I_{t}$ denotes the index of standard tree ring chronology in year $t$ (dimensionless), $I_{t+1}$ is the index of standard tree ring chronology in year $t+1$ (dimensionless), $I_{t+2}$ is the index of standard tree ring chronology in year $t+2$ (dimensionless), and $I_{t+3}$ is the index of standard tree ring chronology in year $t+3$ (dimensionless).

\section{HESSD}

9, 65-91, 2012

\section{Tree ring-based reconstruction in the Jiaolai River since 1826 \\ L. Ma et al.}

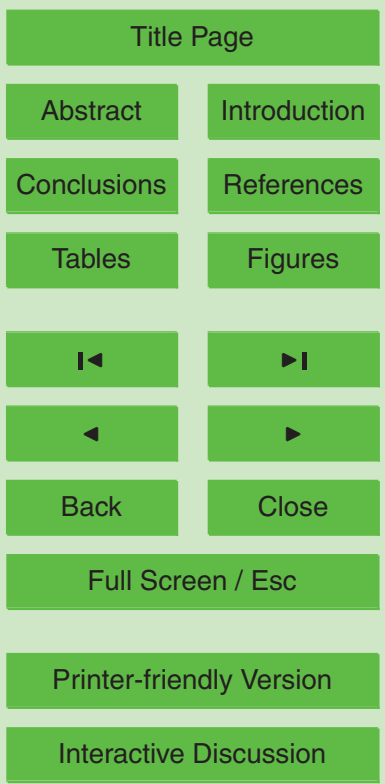


Compared with the reconstructed sequence exhibiting the same trend as the corresponding sequence of the measured value (shown in Fig. 5), some extreme values cannot be completely consistent with the reconstructed values. In other words, part of the tree ring reconstruction results underestimates extreme hydrology and climate events (Fritts, 1976). However, the reconstruction equation yielded good results for the reconstruction of the average minimum winter temperature. The reconstructed and measured values demonstrated good synchronization.

Additional tests on the stability and reliability of the reconstruction equation are necessary to ensure the credibility of the reconstruction value when a value generated 10 beyond the calibration period is used. According to common international practice, the reduction error RE, $S_{1}$ (sign test), $S_{2}$ (first difference symbols for the test), and $t$ (average test value for the product) were calculated. An RE of 0.54, which was obviously greater than 0.3 , was obtained. When $R E$ is higher than 0.3 , the reconstruction value is considered credible ( $\mathrm{Li}$ et al., 2000). The values of the sign test results and 15 first-difference symbols for the test results were $33 / 49$ and $31 / 48$, respectively. These were significant at the 0.05 level, indicating that the reconstructed and measured value sequences were in good agreement with the changes in high-low frequencies. The average test value for the product was 2.91 , which was significant at the 0.01 level, indicating a significant difference between the identical and opposing serial number sequences. All parameters indicated that the reconstruction equation was stable and reliable. The reconstruction results for the runoff derived from this equation were also credible.

Consequently, the runoff series for the XiaWa Station of the JiaoLai River in October to November from 1826 to 2006 was rebuilt according to the reconstruction equation. 25 The reconstruction sequence is shown in Fig. 5.
HESSD

9, 65-91, 2012

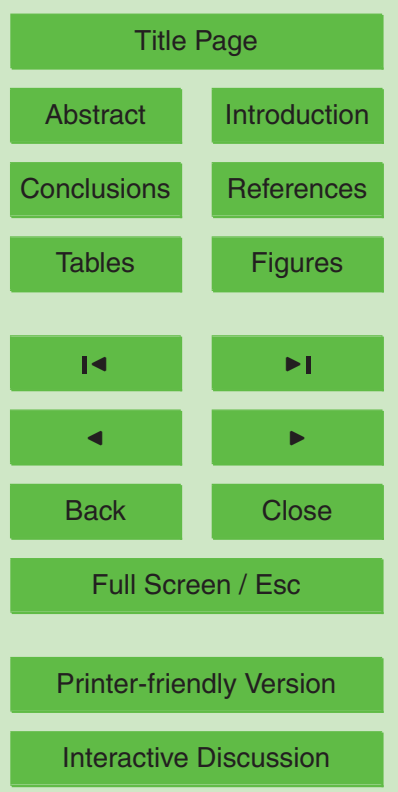




\section{Characteristics of runoff}

\subsection{Changes in wet and dry seasons}

According to the reconstructed runoff series, the average runoff in the XiaWa station of the JiaoLai River in October to November from 1826 to 2006 was 9.7238 million $\mathrm{m}^{3}$, 5 with the maximum being 18.5171 million $\mathrm{m}^{3}$ (occurred in the year 1829). The minimum was 2.8576 million $\mathrm{m}^{3}$ (occurred in the year 2005). The extreme value was 6.48 , which illustrated that the runoff in the JiaoLai River had greater amplitudes between years.

Reconstructing the sequence in mean runoff changes can reflect wet and dry season changes between years. The mean changes are shown in Table 3 . These data showed the wet periods were more obvious in the 1820s, 1850s, 1900s, and 1950s during the era of scale changes, whereas dry periods were remarkable in the 1880s, 1910s, and 1970s-2000s.

For further quantitative analysis of the reconstructed sequences in wet and dry season changes, the coefficient ratio $K_{\mathrm{p}}$, which is the ratio of the runoff to the mean runoff for many years, was calculated. The following definitions were made for different $K_{\mathrm{p}}$ values: more than 1.16, special wet years; between 1.06 and 1.16, partial wet years; between 0.95 and 1.06, flat water years; between 0.84 and 0.95 , partial dry years; and less than 0.84 , special dry years. The reconstruction sequence is shown in Fig. 6 . This sequence indicated that the years of reconstructed sequences in special wet, partial wet, flat water, partial dry, and special dry years were $40,23,40,30$, and 47 , accounting for $22.22 \%, 12.78 \%, 22.22 \%, 16.67 \%$, and $26.11 \%$ of the total number of years. The proportions of special wet, flat water, and special dry years were large, with the largest being that of special dry years. This result revealed that the runoff in the JiaoLai River had a negative contribution to the reconstruction period.

25 According to the principle of at least 5 continuous years, special and partial wet years were combined with wet years, whereas special and partial dry years were combined with dry years. The results are shown in Fig. 6. The consecutive wet years in the reconstruction sequences were 1826 to 1834,1856 to 1861,1872 to 1877,1897 to

\section{Tree ring-based reconstruction in the Jiaolai River since 1826 \\ L. Ma et al.}

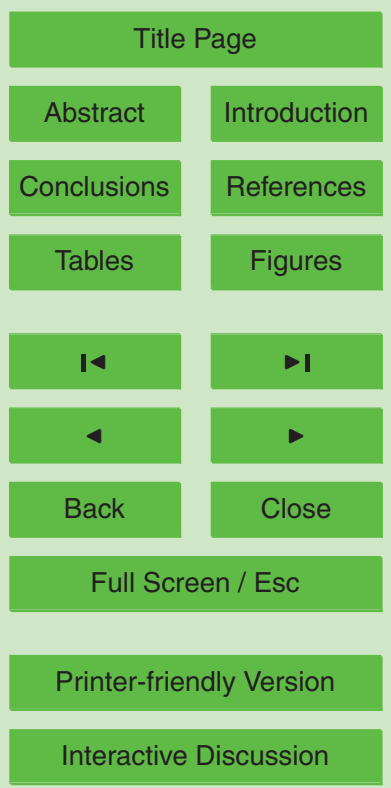


1905, 1938 to 1943 , and 1946 to 1960 . The durations ranged from 6 to $15 \mathrm{yr}$, and the total was $51 \mathrm{yr}$. Of these $51 \mathrm{yr}, 24$ occurred in the 19th century, and the remaining 27 occurred in the 20th century (mainly in the 1960s). The longest wet period occurred from 1946 to 1960 , a total of $15 \mathrm{yr}$, with the mean annual runoff at 12.9962 million $\mathrm{m}^{3}$, 5 which was 1.33 times the average runoff for the entire reconstruction period. There were four periods of continuous dry years, namely, 1835 to 1840,1880 to 1885,1912 to 1922 , and 1982 to 2005 . The durations ranged from 6 to $24 \mathrm{yr}$, and the total was $47 \mathrm{yr}$. Of these $47 \mathrm{yr}$, only 12 occurred in the 19th century, and the remaining 30 occurred in the 20th century (mainly in the 1980s to the late 20th century). The five 10 years in the early 21 st century were continuous dry years (from 1982 to 2005). The continued dry time reached $24 \mathrm{yr}$, and the mean annual runoff was 6.1823 million $\mathrm{m}^{3}$, which was only $63.58 \%$ of the average runoff for the entire reconstruction period. The continuous dry periods occurred not only in the 1980s, but also from the early 1960s to 2005. The overall runoff trend was decreasing. During the 1950 s to 2000 s, the runoff decreased from 14.1031 million $\mathrm{m}^{3}$ to 3.4435 million $\mathrm{m}^{3}$, with drop rate of 1.7766 million $\mathrm{m}^{3} / 10 \mathrm{yr}$. The runoff significantly declined, which fully illustrated that the runoff in the JiaoLai River had been gradually decreasing for nearly $50 \mathrm{yr}$, thereby forming the longest continuous dry season during the reconstruction period.

\subsection{Periodic changes}

20 An analysis of the runoff reconstruction with the power spectrum revealed that the runoff reconstruction sequence had 3-, 11-, 15-, 24-, and 30-yr quasi-periodic variations under the 0.05 significance level. This result had basically the same cycle as the precipitation changes in the Horqin Sandy Land. This similarity signified that precipitation played an important role in the runoff formation.

\section{HESSD}

$9,65-91,2012$

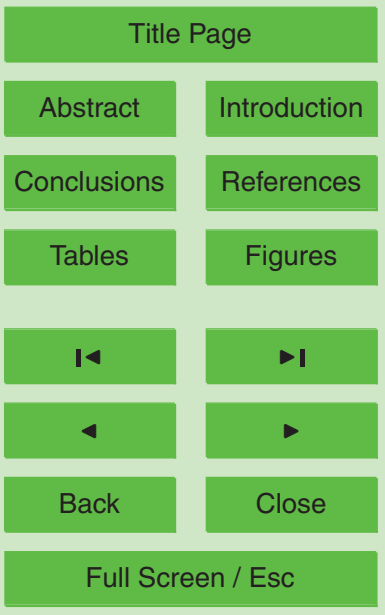

Printer-friendly Version

Interactive Discussion 


\subsection{Variation trends}

The runoff sequence was reconstructed for a 10-yr moving average, as shown in Fig. 7. As can be seen from the trend line, the runoff change was gentler from 1826 to 1917 (92 yr) in the JiaoLai River during the $180 \mathrm{yr}$. Subsequently, the runoff increased in 5 1956, and then for nearly $50 \mathrm{yr}$, significant decreased. This finding was consistent with the aforementioned wet and dry seasonal changes.

\section{Discussion and conclusion}

The present study used a comprehensive timeline for the regional tree wheel width of the Horqin Sandy Land to reconstruct the runoff sequences in the XiaWa station of the 10 JiaoLai River during the months of October to November from 1826 to 2005 . The reconstructed sequence exhibited the same trend as the corresponding sequence of the measured value. The calculated results of various tests showed that the reconstruction result was stable and reliable.

There were greater amplitudes in runoffs in the JiaoLai River between years. The 15 reconstruction sequence had six continuous wet period years, a total of $51 \mathrm{yr}$, including $27 \mathrm{yr}$ that occurred in the early 20 th century to the early $1960 \mathrm{~s}$. The multi-year average runoff in the wet period from 1946 to 1960 was 1.33 times the entire reconstruction period mean annual runoff. The runoff also went through four continuous dry periods, a total of $47 \mathrm{yr}$, which had $30 \mathrm{yr}$ occurring in the 1980 s to the late 20th century. The multiyear average runoff from 1982 to 2005 was only $63.58 \%$ of the entire reconstruction period. Overall, the runoff gradually decreased for nearly $50 \mathrm{yr}$, from the early $1960 \mathrm{~s}$ to the present, and the drop rate in runoff was 1.7766 million years $\mathrm{m}^{3} / 10 \mathrm{yr}$. This result indicated that the runoff significantly decreased, and the total reduction was $75.58 \%$ of the initial value.

25 Runoff in the JiaoLai River had 3-, 11-, 15-, 24-, and 30-yr quasi-periodic variations. Among them, the 11-yr variation had the same cycle with solar activity. The 24- and
HESSD

9, 65-91, 2012

Tree ring-based reconstruction in the Jiaolai River since 1826

L. Ma et al.

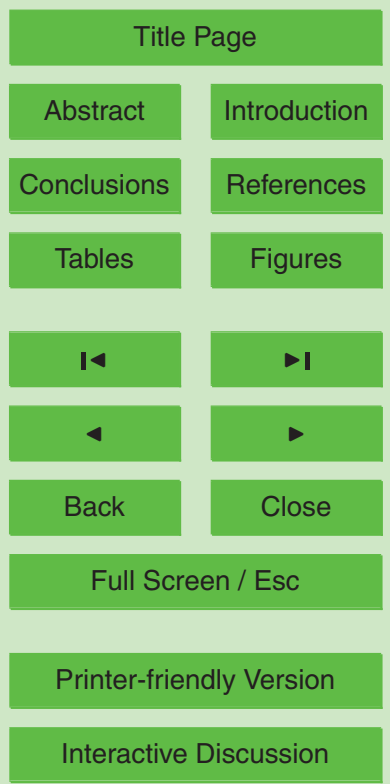


30-yr cycles were also consistent with the precipitation cycle. This result fully explained that the runoff change in the JiaoLai River followed certain rules, with varying degrees of change similar with other areas around the globe.

Overall, during the nearly $180 \mathrm{yr}$ in the JiaoLai River, the change in runoff was gentler 5 from 1917 to 1826 . Then, in 1956, the runoff gradually decreased. In nearly $50 \mathrm{yr}$, the runoff had a significant decreasing trend. A comparison with the ten year sliding curve of precipitation in the Horqin Sandy measured in July to November (Fig. 7) revealed that the precipitation decreased for nearly $50 \mathrm{yr}$, i.e. from $296.10 \mathrm{~mm}$ to $207.67 \mathrm{~mm}$ in the $1950 \mathrm{~s}$ to $2000 \mathrm{~s}$, with the decreased rate of $14.74 \mathrm{~mm} / 10 \mathrm{yr}$. The overall decrease 10 accounted for $29.86 \%$ of the initial value, which is a significant amount. In contrast, the proportional decrease in precipitation accounted for the initial value being much smaller than the proportion of runoff reduction, accounting for about half. In other words, a slight decrease in precipitation may lead to a significant reduction in runoff. Zhang et al. (2007) have drawn relatively similar conclusion. They propose that in the past $50 \mathrm{yr}$, the relationship between runoff and precipitation had an overall downward trend. The results of the present study provide further references on runoff changes in the Liaohe River, as well as possible strategies for ecological environmental protection and catchment economy progress.

Acknowledgements. This research was supported by National natural science funds projects 20 (Grant No: 50869005) , Inner Mongolia natural science fund projects(Grant No: 2010BS0608) and Inner Mongolia Agricultural University of "cold-dry water resources utilization" innovation team to plan funding.

\section{References}

Battipaglia, G., Frank, D., Büntger, U., Dobrovolný, P., Brázil, R., Pfister, C., and Esper, J.: Five centuries of Central European temperature extremes reconstructed from tree-ring density and documentary evidence, Global Planet. Change, 72, 182-191, 2010.

Briffa, K. R., Jones, P. D., and Schweinguber, F. H., Shiyatov, S. G., and Cook, E. R.: Unusual

\section{HESSD}

$9,65-91,2012$

\section{Tree ring-based reconstruction in the Jiaolai River since 1826 \\ L. Ma et al.}

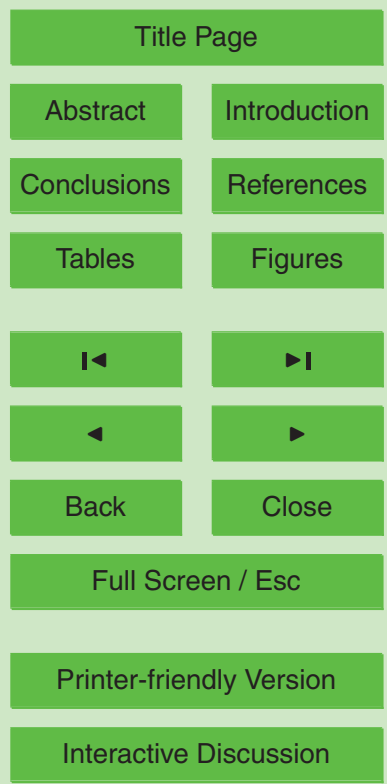


twentiet h-century summer warmt hin a 1000-year temperature record f rom Siberia, Nature., 376, 156-159, 1995.

Clevel, M. K.: A 963-year reconstruction of summer (JJA) stre-amflow in theWhite River, Arkansas, USA, from tree-rings, The Holocene, 10, 33-41, 2000.

5 Cook, E. R. and Jacoby, G. C.: Potomac River stream flow since 1730 as reconstruction tree rings, J. Clim. Appl. Meteorol., 22, 1659-1672, 1983.

Dong, G. R., Jin, H. L., and Chen, H. Z.: Geneses of desertification in semiarid and subhumid regions of northern China, Quaternary Sci., 2, 136-144, 1998.

Eryuan, L., Shao, X. M., and Qin, N. S.: Tree-ring based summer temperature reconstruction for the source region of the Yangtze River on the Tibetan Plateau, Global Planet. Change., 61, 313-320, 2008.

Esper, J., Cook, E. D., and Schweingruber, F. H.: Test of the RCS met hod for preserving low-frequency variability in long tree-ring chronologies, Tree-Ring Res., 59, 81-98, 2003.

Fang, X. Q., Ren, L. L., and Li, Q. F.: Variations of hydrological elements in Laohahe River

15 Basin, Journal of Hohai University (Natural Sciences), 37, 620-624, 2009.

Fritts, H. C.: Tree ring and climate,London: Academic Press., 6-8, 1976.

Gou, X. H., Yang, M. X., Peng, J. F., and Li, Q. F.: Maximun temperature reconstruction for Animaqing mountain over past 830 yeara based on tree-ring records, Quaternary Sci., 26, 991-998, 2006.

$20 \mathrm{Gu}, \mathrm{Y}$., Wang, X. L., and Lin, J.: Analysis on change and trend of dry season runoff for major rivers in china since past 60 years, Water Resources and Hydropower Engineering, 4, 131137, 011.

Hao, L., Wang, J. A., Gao, L., and Shao, X. M.: On the runoff in Laohahe river basin in the last 40 years, Journal of Beijing Normal University(Natural Science), 44, 629-633, 2008.

Helama, S., Seppä, H., Birks, H. J. B., and Bjune, A. E.: Reconciling pollen-stratigraphical and tree-ring evidence for high- and low-frequency temperature variability in the past millennium, Quaternary Sci. Rev., 29, 3905-3918, 2010.

Hughes, M. K., Leggett, P., Gray, B., Chen, H. Z., and Qin, N. S.: Climatic signals in Briti Isles tree-ring chronologies, Nature, 72, 605-606, 1978.

30 Jiang, S. H., Ren, L. L., Yong, B., Yang, M. X., and Ren, L. L.: The effects of climate variability and human activities on runoff from the Laohahe River Basin in Northern China, Water Resources Protection, 26, 1-15, 2010.

Kang, L. L., Wang, Y. Z., Ma, Y., and Zhai, L. X.: Reconstruction of the natural runoff Series
HESSD

9, 65-91, 2012

\section{Tree ring-based reconstruction in the Jiaolai River since 1826}

L. Ma et al.

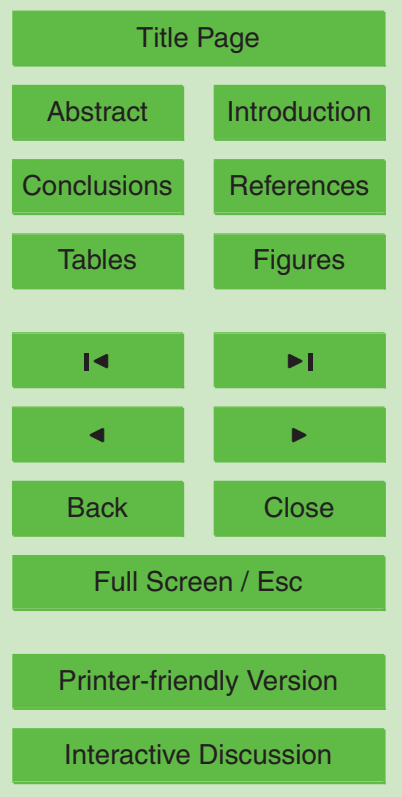


in recent 523 years at Huayuankou station in Yellow River, Journal of Water Resources and Water Engineering., 19, 10-13, 2008.

Kang, X. C., Chen, G. D., Kang, E. S., Shao, X. M., and Qin, N. S.: Reconstruction the export runoff in the Black River using tree rings in nearly thansoud years, Science in China, Ser. D., $5 \quad 32,675-685,2002$.

Law, B. E., Turner, D., Lefsky, M., Yang, M. X., and Peng, J. F.: Carbon fluxes across regions: Ob-servational constraints at multiple scales, in: Scaling and Uncertainty Analysis in Ecology: Methods and Appli-cations, edited by: Wu, J., Jones, B., and Li, H., and Yong, B., New York: Columbia University Press, 167-190, 2006.

10 Li, A. M., Han, Z. W., Huang, C. H., and Chen, G. D.: Remote sensing monitoring on dynamic of sandy desertification degree in Horqin Sandy Land at the beginning of 21st century, Journal of Desert Research, 27, 546-551, 2006.

Li, J. F., Yuan, Y. J., You, X. R., and Huang, C. H.: A-360 years ' runoff reconstruction in the RMQI river basin using tree rings, China Quaternary Sciences, 2, 131-137, 1997.

15 Li, J. F., Yuan, Y. J., You, X. R., and Huang, C. H.: The research and application in tree-ring hydrology, Beijing, Science, 4, 106-107, 2000.

Li, Q., Feng, Q., and Zhai, L. X.: Study of the height growth dynamic based on tree-ring data in Populus euphratica from the lower reach of the Heihe River, China, Dendrochronologia, 28, 49-64, 2010.

20 Liu, P. X., Chen, F. H., Jin, L. Y., and Zhai, L. X.: About 100-year reconstruction of spring streamflow based on tree rings in the lower reaches of Heihe River, Arid Land Geography, 30, 696-700, 2007.

Liu, X. H., Qin, D. H., Shao, X. M., Yuan, Y. J., and You, X. R.: Temperature changes in the middle Qilian Mountain over the last millennium using tree-rings record, Science in China,

25 Ser. D., 34, 89-95, 2004.

Liu, Y., Tian, H., Song, H. M., and Jin, L. Y.: Tree ring based reconstruction of the May-June mean temperature since A.D.1884, in WeiChang, HeBei province, China Quaternary Sciences., 29, 896-904, 2009a.

Liu, Y., Yang, Y. K., Cai, Q. F., and Song, H. M.: Tree ring based reconstruction of the June-July 30 runoff in HuangShui since past 248 years, Journal of Arid Land Resources and Environment, 20, 69-73, 2009b.

Liu, Y., Sun, J. Y., Song, H. M., and Liu, T. X.: Tree-ring hydrologic reconstructions for the Heihe River watershed, western China since AD 1430, Water Res., 44, 2781-2792, 2010.

\section{HESSD}

9, 65-91, 2012

\section{Tree ring-based reconstruction in the Jiaolai River since 1826}

L. Ma et al.

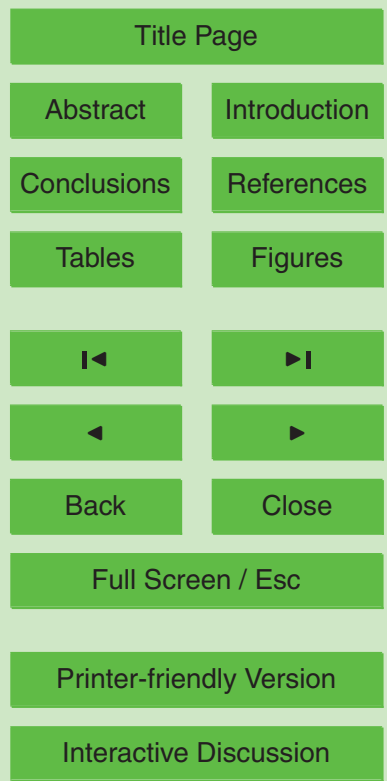


Loso, M. G., Anderson, R. S., Anderson, S. P., and Reimer, P. J.: A 1500-year record of temperature and glacial response inferred from varved Iceberg Lake, southcentral Alaska, Quaternary Res., 66, 12-24, 2006.

Ma, L. and Liu, T. X.: Relationship of Elm growth and hydrometeorological factors of Horqin 5 Sandy Land and climatic series reconstruction, Journal of Glaciology and Geocryology, 29, 802-807, 2009.

Ma, L., Liu, T. X., Jin, H. L., and Song, H. M.: Reconstruction in elm tree-ring width chronologies and precipitation in Horqin sandySince 1826, China Quaternary Sciences, 31, 360-369, 2011.

10 Magda, V. N., Zelenova, A. V., and Andreev, S. G.: A 280-year reconstruction of Baikal Lake water level from treerings, Confercnce "Tree Rings and Peopl", 22-26, 2001.

Martinelli, N.: Climate from dendrochronology: Latest developments and results, Global Planet Change., 40, 129-139,2004.

McAuliffe, J. R., Scuderi, L. A., and McFadden, L. D.: Tree-ring record of hillslope erosion and 15 valley floor dynamics:Landscape responses to climate variation during the last $400 \mathrm{yr}$ in the Colorado Plateau, northeastern Arizona, Global Planet. Change, 50, 184-201, 2006.

Meko, D. M., Therrell, M. D., Baisan, C. H., and Hughes, M. K.: Sacramento River flow reconstructed to A.D. 869 from tree rings, J. Am. Water Resour. As., 37, 1029-1040, 2001.

Qin, N. S., Jin, L. Y., Shi, X. H., and Jin, H. L.: A 518-year runoff reconstruction of Tongtian river basin using tree-ring width chronologies, Acta Geogr. Sinica, 59, 550-556, 2004.

Rickebusch, S., Lischke, H., Bugmann, H., Guisan, A., and Zimmermann, N. E.: Understanding the low-temperature limitations to forest growth through calibration of a forest dynamics model with tree-ring data, Forest Ecol. Manage., 246, 251-263, 1997.

Shao, X. M.: Some development of chronology round the tree, Quaternary Sci., 3, 265-271, 1997a.

Shao, X. M., Huang, L., Liu, H. B., and Shi, X. H.: Precipitation in Qinghai Millennium Delhi region using tree-ring record, Science in China, Ser. D., 34, 145-153, 1997b.

Shao, X. M., Wang, S. Z., Xu, Y., and Shi, X. H.: A 3500-year master tree-ring dating chronology from the northeast part of the Qaidam Basin, Quaternary Sci., 27, 477-485, 1997c.

30 Stockton, C. W. and Meko, D. M.: A long-term history of drought occur-rence in western United States as inferred from tree rings, Weatherwise, 28, 245-249, 1975.

Sun, J. Y., Liu, Y., Cai, Q. F., and Zhu, Z. D.: Tree-ring based reconstruction of June-July for the DaTong river watershed runoff, western china since AD 1525, Marine Geology \& Quaternary

\section{HESSD}

9, 65-91, 2012

\section{Tree ring-based reconstruction in the Jiaolai River since 1826}

L. Ma et al.

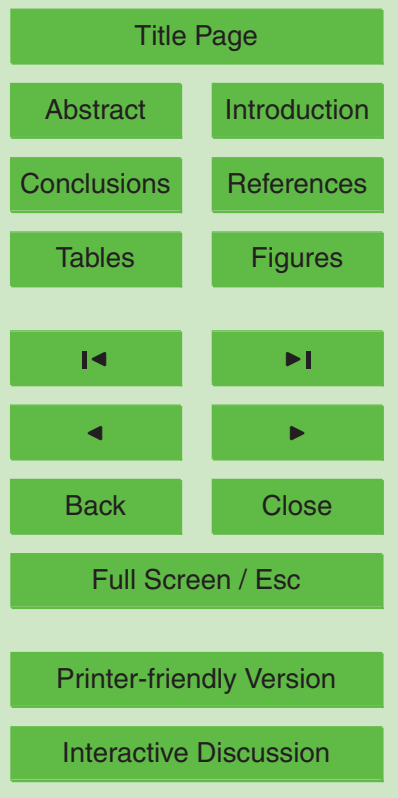


Geology, 31, 109-115, 2011.

Van, R. B., Stahle, D. W., and Cleaveland, M. K.: Earthquake signals in tree-ring data from the New Madrid Seismic zone and implications for paleoseimicity, Geology, 26, 515-518, 1998.

Wang, G. Q., Jin, J. L., Wang, J. X., Liu, Y., and Cai, Q. F.: Study on hydrological characteristics of Liaohe River basin in response to climate change, Adv. Earth Sci., 26, 433-440, 2011.

Wang, T. and Zhu, Z. D.: The desertification problems of northern China, Quaternary Sci., 21, 56-65, 2004.

Wang, T., Zhu, Z. D., and Wu, W.: Sandy desertification in the north China, Science in China, Ser. D., 45, 23-34, 2002.

10 Wang, T., Wu, W., Xue, X., and Zhu, Z. D.: Spatial-temporal changes of sandy desertified Land during Last five decades in northern china, Acta Geogr. Sinica, 59, 203-212, 2004a.

Wang, T., Wu, W., Zhao, H. L., Xue, X., and Chen, G. T.: Analyses on driving factors to sandy desertification process in Horqin region, China Journal of Desert Research, 24, 519-528, 2004b.

Wang, T., Chen, G. T., Zhao, H. L., and Wu, W.: Research progress on aeolian desertification process and controlling in north of china, Journal of Desert Research, 226, 507-516, 2011.

Wang, Y. J., Chen, F. H., Gou, X. H., and Zhu, Z. D.: Change in runoff. During March to June in Heihe since 230-year ago, China Journal of Desert Research, 26, 202-206, 2004.

Woodhouse, C. A.: A tree-ring reconstruction of streamflow for the Colorado FrontRange, J. $20 \quad$ Am. Water Resour. As., 37, 561-570, 2001.

Wu, X. D., Sun, L., and Zhan, X. Z.: The initial attempt on past climate in central Tibet use of tree-ring reconstruction, Acta Geogr. Sinica., 44, 334-341, 2001.

Yang, H. S., Liu, J., and Liang, H. Y.: Change characteristics of climate and water resources in west Liaohe River Plain, Chinese Journal of Applied Ecology., 20, 84-90, 2009.

Zhang, J. and He, J. S.: Analysis of runoff series characteristics in the Liaohe Basin, China Rural Water and Hydropower, 4, 10-13, 2011.

Zhang, J. Y., Zhang, S. L., Wang, J. X., and He, J. S.: Study on runoff trends of the six larger basins in China over the past 50 years, Adv. Water Sci., 18, 230-234, 2011.

Zhao, H. L., Zhou, R. L., and Liang, H. Y.: Effects of human activity and climate changes on 30 vegetation in Horqin Sandy grassland, Inner Mongolia, Adv. Earth Sci., 23, 408-414, 2008.

Zhu, H. F., Zheng, Y. H., Shao, X. M., and Zhang, S. L.: The temperature changes on Qing Hai Wu Lan based on tree-ring record nearly thousand years, Chinese Sci. Bull., 53, 1835-1841, 2008.

\section{HESSD}

$9,65-91,2012$

\section{Tree ring-based reconstruction in the Jiaolai River since 1826}

L. Ma et al.

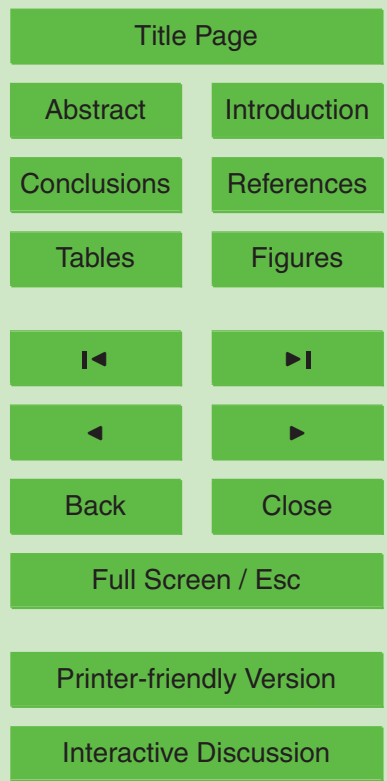




\section{HESSD}

9, 65-91, 2012

\section{Tree ring-based reconstruction in the Jiaolai River since 1826}

L. Ma et al.

Table 1. Correlation coefficient of standard chronology and runoff.

\begin{tabular}{|c|c|c|c|c|c|c|c|}
\hline & $\begin{array}{l}\text { Runoff in } \\
\text { March }\end{array}$ & $\begin{array}{l}\text { Runoff in } \\
\text { April }\end{array}$ & $\begin{array}{l}\text { Runoff in } \\
\text { August }\end{array}$ & $\begin{array}{l}\text { Runoff in } \\
\text { September }\end{array}$ & $\begin{array}{l}\text { Runoff in } \\
\text { October }\end{array}$ & $\begin{array}{l}\text { Runoff in } \\
\text { November }\end{array}$ & $\begin{array}{l}\text { Annual } \\
\text { Runoff }\end{array}$ \\
\hline Standard chronology & $0.365^{\star \star}$ & $0.296^{*}$ & $0.455^{\star \star}$ & & $0.512^{\star \star}$ & $0.549^{\star *}$ & $0.281^{*}$ \\
\hline Standard chronology in year $t+1$ & $0.384^{\star *}$ & $0.491^{* *}$ & $0.298^{\star}$ & & $0.483^{\star *}$ & $0.545^{\star *}$ & $0.277^{*}$ \\
\hline Standard chronology in year $t+2$ & $0.301^{*}$ & $0.374^{\star *}$ & $0.449^{* *}$ & & $0.520^{* *}$ & $0.584^{* *}$ & $0.454^{\star *}$ \\
\hline Standard chronology in year $t+3$ & $0.444^{* *}$ & $0.558^{* *}$ & $0.386^{\star *}$ & $0.368^{* *}$ & $0.566^{* *}$ & $0.626^{* *}$ & $0.455^{\star *}$ \\
\hline
\end{tabular}

Note: ${ }^{* \star}$ is $99 \%$ confidence level, ${ }^{*}$ is $95 \%$ confidence level.

Title Page

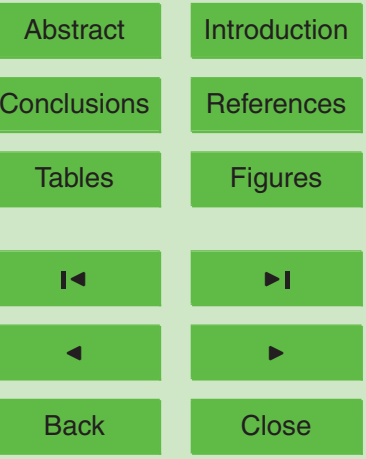

Full Screen / Esc

Printer-friendly Version

Interactive Discussion 


\section{HESSD}

9, 65-91, 2012

\section{Tree ring-based reconstruction in the Jiaolai River since 1826 \\ L. Ma et al.}

Table 2. Correlation coefficients of runoff and precipitation.

\begin{tabular}{|c|c|c|c|c|c|c|c|c|}
\hline & $\begin{array}{l}\text { Runoff in } \\
\text { March }\end{array}$ & $\begin{array}{l}\text { Runoff in } \\
\text { April }\end{array}$ & $\begin{array}{l}\text { Runoff in } \\
\text { July }\end{array}$ & $\begin{array}{l}\text { Runoff in } \\
\text { August }\end{array}$ & $\begin{array}{l}\text { Runoff in } \\
\text { September }\end{array}$ & $\begin{array}{l}\text { Runoff in } \\
\text { October }\end{array}$ & $\begin{array}{l}\text { Runoff in } \\
\text { November }\end{array}$ & $\begin{array}{l}\text { Annual } \\
\text { Runoff }\end{array}$ \\
\hline Precipitation in July & $0.395^{\star \star}$ & $0.293^{*}$ & $0.469^{\star \star}$ & $0.288^{\star}$ & $0.398^{\star \star}$ & $0.366^{\star \star}$ & $0.445^{\star \star}$ & $0.519^{\star \star}$ \\
\hline Precipitation in August & & & & $0.572^{\star \star}$ & $0.414^{\star \star}$ & $0.329^{\star}$ & & $0.283^{*}$ \\
\hline Precipitation in September & & & & & $0.574^{\star \star}$ & $0.291^{\star}$ & $0.285^{\star}$ & \\
\hline Annual Precipitation & $0.276^{\star}$ & $0.316^{*}$ & $0.443^{\star *}$ & $0.359^{\star \star}$ & $0.417^{\star *}$ & $0.415^{\star \star}$ & $0.430^{\star *}$ & $0.381^{\star *}$ \\
\hline
\end{tabular}

Note: ${ }^{*}$ is $99 \%$ confidence level, ${ }^{*}$ is $95 \%$ confidence level.

Title Page

\section{Abstract}

Introduction

Conclusions

References

Tables

Figures

14

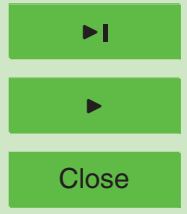

Back

Full Screen / Esc

Printer-friendly Version

Interactive Discussion 


\section{HESSD}

$9,65-91,2012$

Table 3. Mean runoff changes in the reconstruction sequence.

\begin{tabular}{lrrr}
\hline Times & $\begin{array}{r}\text { Mean runoff } \\
\left(\times 10000 \mathrm{~m}^{3}\right)\end{array}$ & Times & $\begin{array}{r}\text { Mean runoff } \\
\left(\times 10000 \mathrm{~m}^{3}\right)\end{array}$ \\
\hline $1820 \mathrm{~s}$ & 1415.61 & $1920 \mathrm{~s}$ & 911.33 \\
$1830 \mathrm{~s}$ & 1017.40 & $1930 \mathrm{~s}$ & 1019.15 \\
$1840 \mathrm{~s}$ & 975.48 & $1940 \mathrm{~s}$ & 1119.74 \\
$1850 \mathrm{~s}$ & 1225.76 & $1950 \mathrm{~s}$ & 1410.31 \\
$1860 \mathrm{~s}$ & 961.44 & $1960 \mathrm{~s}$ & 972.87 \\
$1870 \mathrm{~s}$ & 1088.97 & $1970 \mathrm{~s}$ & 887.31 \\
$1880 \mathrm{~s}$ & 719.28 & $1980 \mathrm{~s}$ & 824.57 \\
$1890 \mathrm{~s}$ & 971.15 & $1990 \mathrm{~s}$ & 635.25 \\
$1900 \mathrm{~s}$ & 1127.83 & $2000 \mathrm{~s}$ & 344.35 \\
$1910 \mathrm{~s}$ & 862.07 & & \\
\hline
\end{tabular}

\section{Tree ring-based} reconstruction in the Jiaolai River since 1826

L. Ma et al.

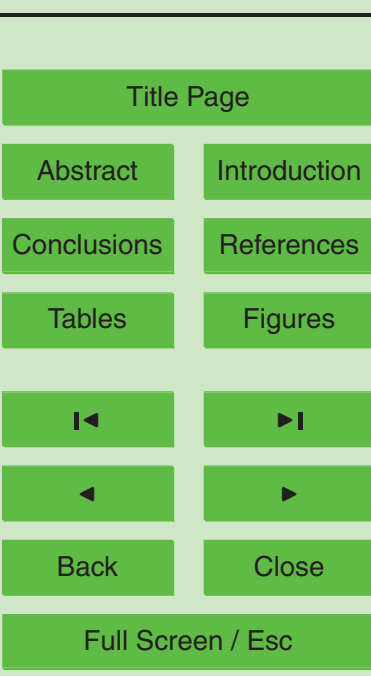

Printer-friendly Version

Interactive Discussion 


\section{HESSD}

9, 65-91, 2012

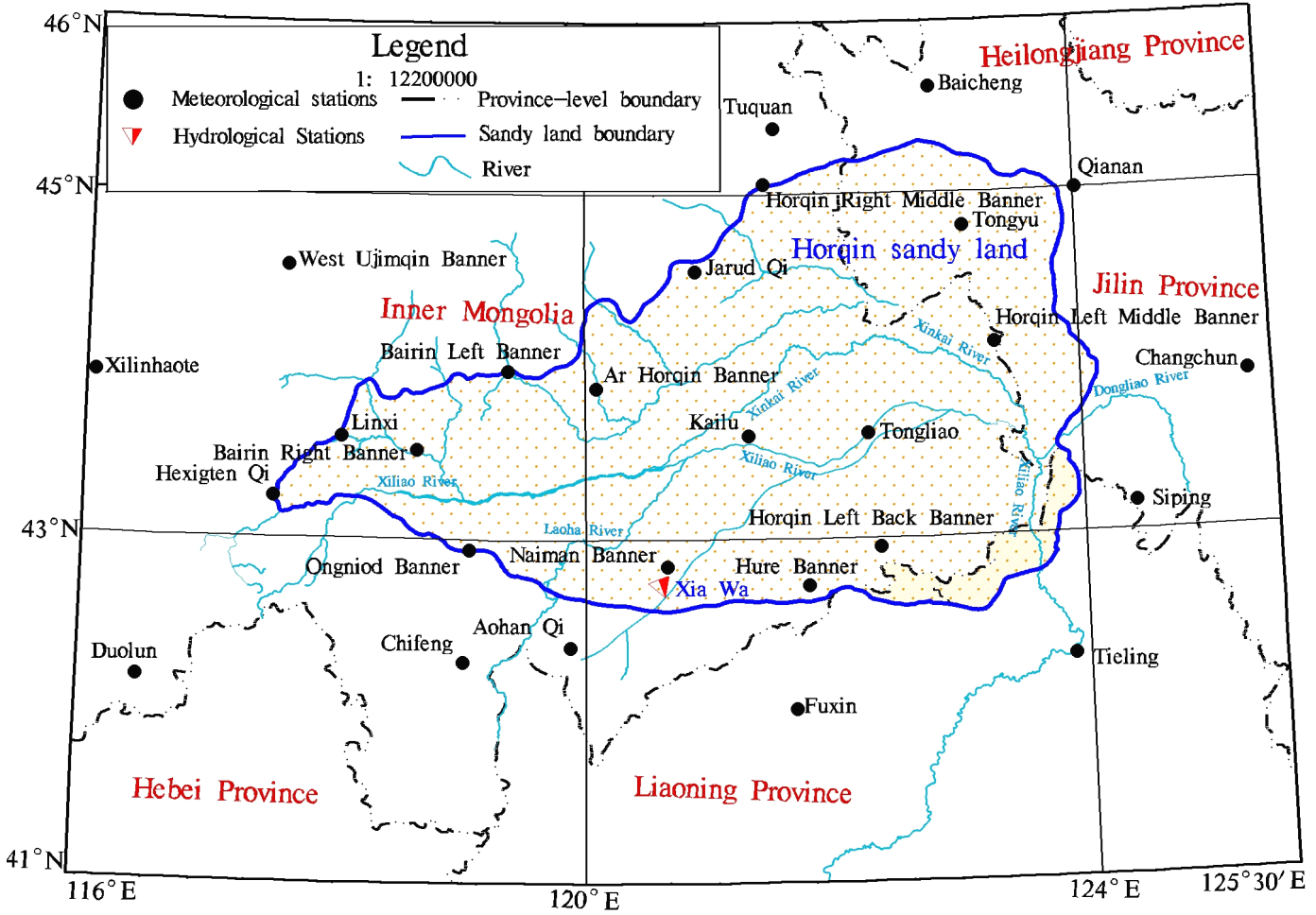

\section{Tree ring-based reconstruction in the Jiaolai River since 1826 \\ L. Ma et al.}

\section{Title Page}

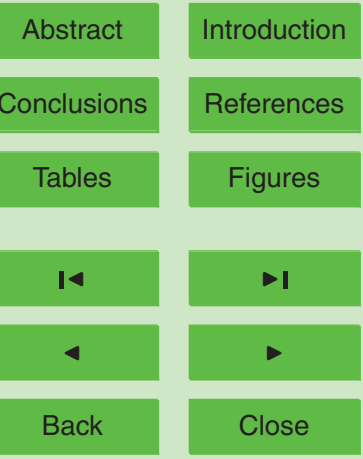

Full Screen / Esc

Fig. 1. Location of the Horqin Sandy Land: meteorological station and runoff stand distribution. 


\section{HESSD}

9, 65-91, 2012

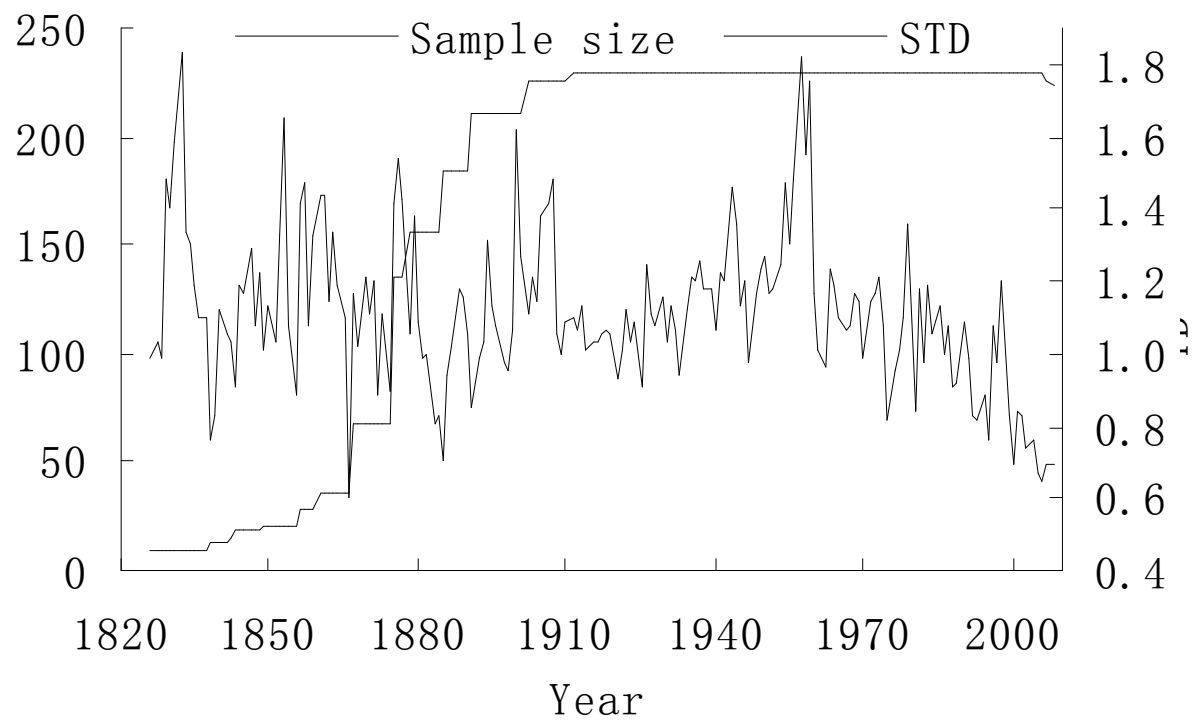

\section{Tree ring-based} reconstruction in the Jiaolai River since 1826

L. Ma et al.

Title Page

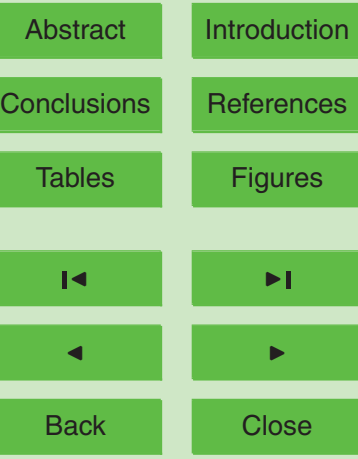

Full Screen / Esc

Printer-friendly Version

Interactive Discussion 


\section{HESSD}

9, 65-91, 2012

\section{Tree ring-based} reconstruction in the Jiaolai River since 1826

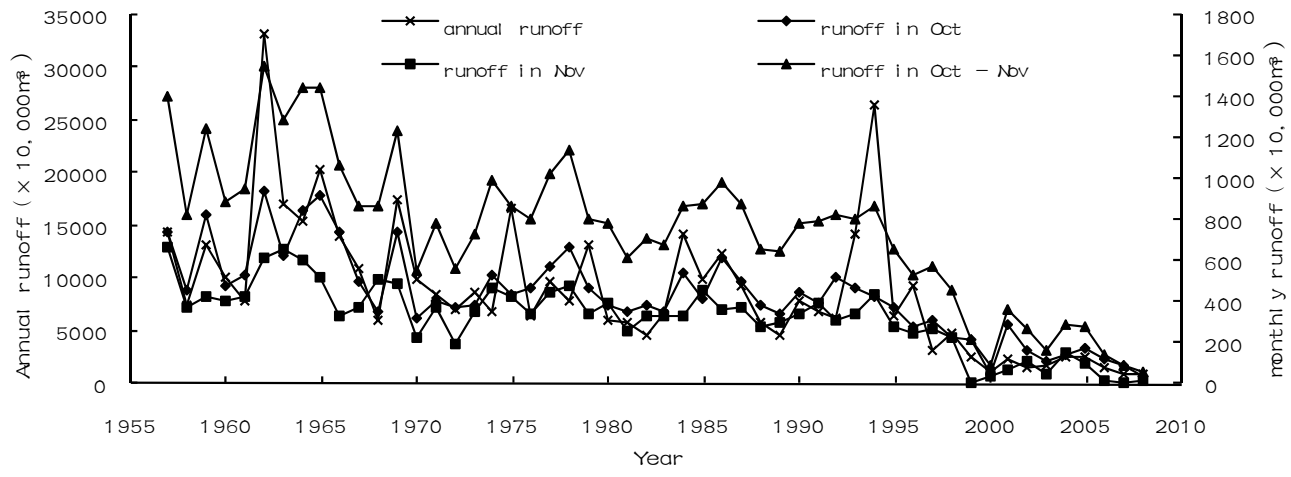

Fig. 3. Contrast curve among the annual runoff, runoff in October, runoff in November, as well as the added runoffs of October and November. 


\section{HESSD}

9, 65-91, 2012

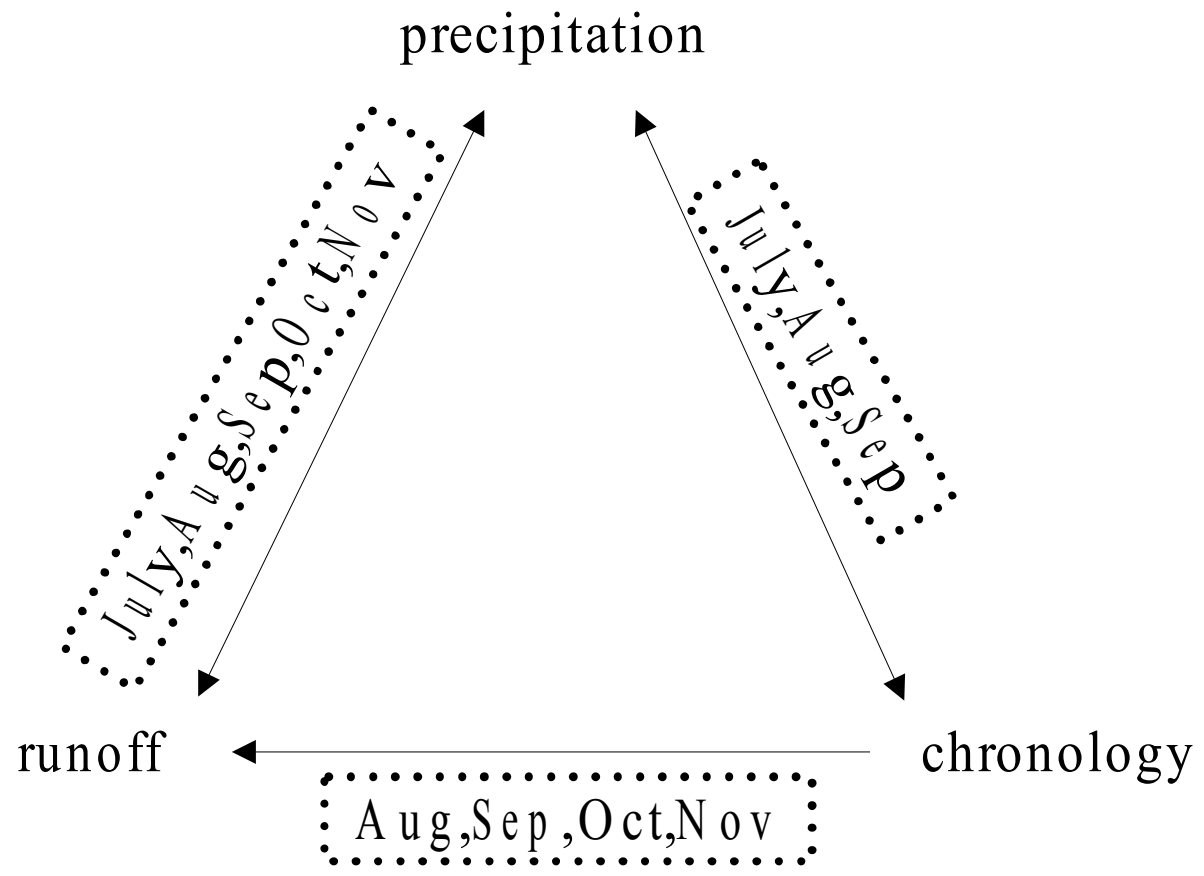

\section{Tree ring-based} reconstruction in the Jiaolai River since 1826

L. Ma et al.

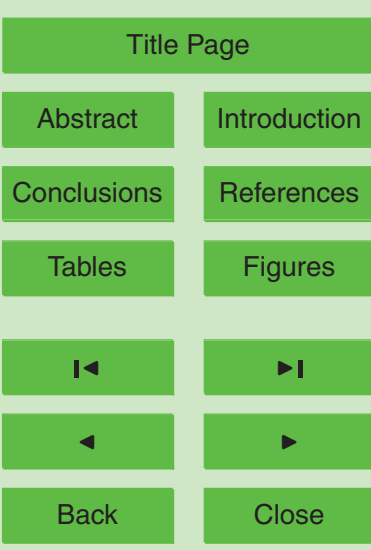

Fig. 4. Correlation of precipitation, runoff, and chronology.

Full Screen / Esc

Printer-friendly Version

Interactive Discussion 


\section{HESSD}

9, 65-91, 2012

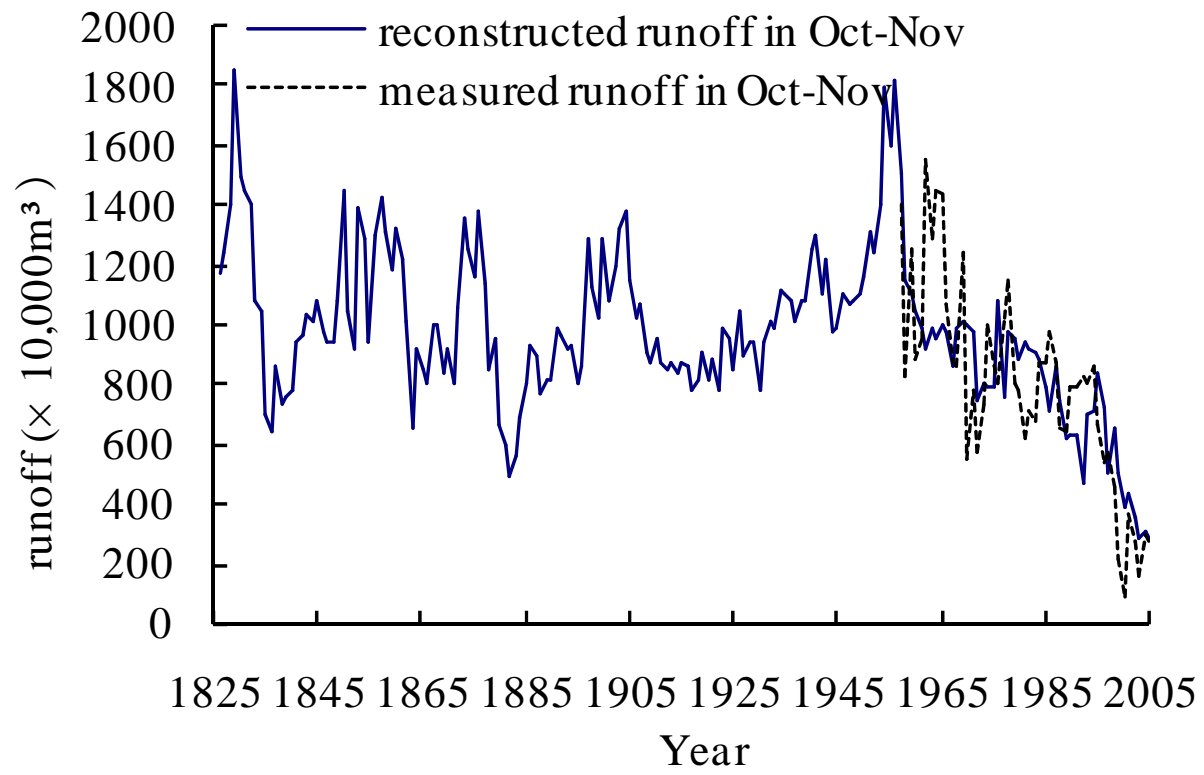

Fig. 5. Contrast curve of the runoff in measured and reconstructed values in October and November.

\section{Tree ring-based} reconstruction in the Jiaolai River since 1826

L. Ma et al.

\section{Title Page}

\section{Abstract}

Introduction

Conclusions

References

Tables

Figures

14

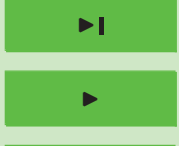

Back

Close

Full Screen / Esc

Printer-friendly Version

Interactive Discussion 


\section{HESSD}

$9,65-91,2012$

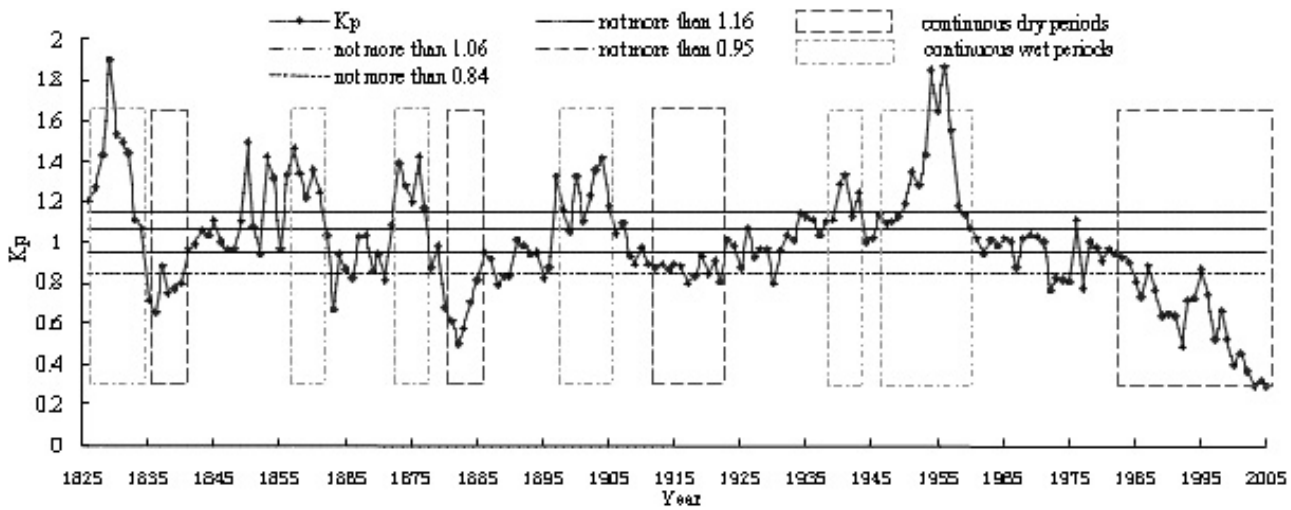

Fig. 6. Changes in the runoff reconstruction sequence $K_{\mathrm{p}}$ as well as the distribution in continuous wet and dry season times.

\section{Tree ring-based Jiaolai River since 1826 \\ L. Ma et al.} reconstruction in the

Title Page

Abstract Introduction

Conclusions References

Tables

Figures

14

4

Back

Close

Printer-friendly Version

Interactive Discussion 


\section{HESSD}

9, 65-91, 2012

\section{Tree ring-based} reconstruction in the Jiaolai River since 1826

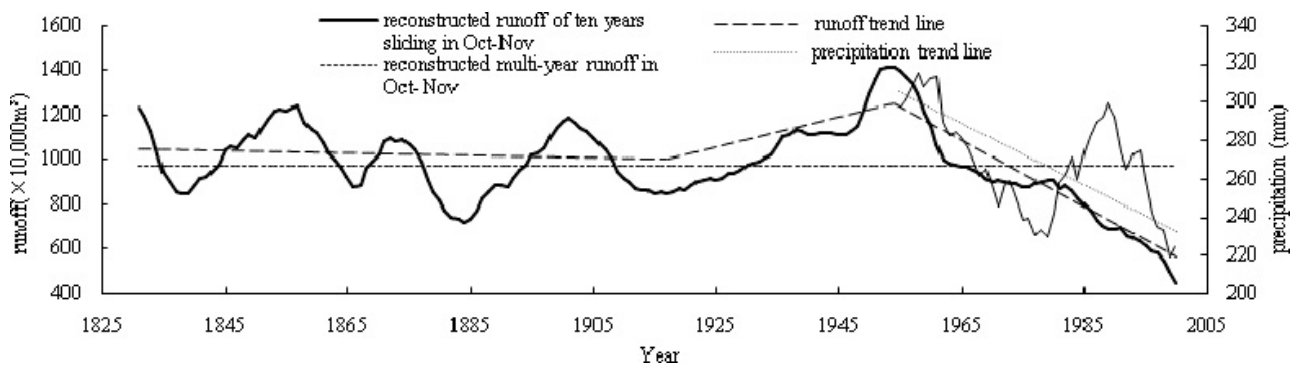

L. Ma et al.

Fig. 7. Sliding changes and trends in the runoff reconstruction sequence and the measured precipitation for ten years. 